心臓のみならず末梢循環に対しても治療効果を示すと考 えられ，右心機能の補助手段の一つとして有用であると 思われた。

文 献 1) Murphy, D. A., Mable, A. E., Landymore, R., et al.: J. Thorac. Cardiovasc. Surg., 76:483, 1978 . 2)
Schemin, R. J., Merill, W. H., Pfeifer, J. S., et al.: J. Thorac. Cardiovasc. Surg., $77: 685,1979 . \quad 3)$ Miller, P. G., Moreno-Cabral, R. J., Stinson, E. B., et al.: J. Thorac. Cardiovasc. Surg., $80: 760,1680$. 4) Jinden, M. B.: Circulation $48: 463$, 1973. 5) Frederic, R. K., James, F. F., and Jan P. S.: Am. J. Physiol., 226: 240, $1974 . \quad 6)$ Stephen, F. E., Irving, H. Z., and Joseph, P. G.: Circ. Res., 46: 726, 1980.

\title{
B-2 三尖弁閉鎖症の外科治療
}

\begin{tabular}{|c|c|c|c|c|c|c|c|c|c|c|c|c|c|}
\hline & & & & & & 学大学 & 胸部 & & & & & & \\
\hline 藤 & 剛 & 毅 & 水 & 野 & & 明 & 古 & 瀬 & & 彰 & 須 & 藤 & 憲 - \\
\hline 塚 & & 裕 & 柳 & 生 & 邦 & 良 & 和 & $\sqrt{\bar{x}}$ & - & 夫 & 宮 & 脇 & 富士夫 \\
\hline
\end{tabular}

1971 年 Fontan，Kreutzer らによる右房肺動脈血行 再建術が報告されて以来, 本症の外科治療について, 従 来の，姑息的手術を含めた計画的治療に関心がもたれて いる. 教室の外科手術例を分析してこれらの点を検討し た.

\section{対象と方法}

1960 年以来 12 例の本症に対し計 16 回の手術を行っ た。初回手術時年令は最小生後 3 月, 最長 16 才で， 2 才以下 6 例, 10 才以上 3 例, 平均 4.8 才であった. 病 型は Ia 1 例，Ib 7 例，Ic 2 例，IIb 1 例，IIc 1 例 であった。低肺血流量群に対しては，Blalock-Taussig (B-T) 術, Glenn 術を計 12 例飞行い, 高肺血流量群 Ic の 2 例飞対 乙肺動脈絞把術 (PAB) 兼心房中隔欠損 (ASD) 桩大形成術を行った，機能的根治術として Fon$\tan$ 手術特よび Björk 手術を各 1 例に施行した。

\section{成績}

病院死は 2 例 (16.6\%) そ2られた. Ib 型に B-T 術 を行った 1.5 才児，特よび IIb 型に Glenn 術を行った 3 才児の 2 例でいずれも初期症例であった（表 1 ）。遠 隔死は 4 例認めら机た。 らち 2 例は Ic 型で, 1.5 才 で PAB 兼 ASD 拡大術を加壳た 1 例は 5 才時に他院で 手術死した. 生後 4 カ月で PAB 兼 ASD 形成術を行っ た他の 1 例は 2 カ月後心不全死した。他の 2 例は Ib 型 および IIc 型で，いず机も 10 才で来院し Glenn 手術 を受けたが 16 年 2 月， 12 年 3 月目に死亡している。

Glenn 手術は最小 1 才，最長 16 才，主に $6 \sim 10$ 才
表 1 Result

\begin{tabular}{llll}
\hline \multicolumn{1}{c}{ OP } & case & \multicolumn{2}{c}{ death } \\
\hline PA bunding & 2 & 0 & 2 \\
ASD creation & $5^{*}$ & 1 & 0 \\
B-T & $7^{*}$ & 1 & 2 \\
Glenn & 1 & 0 & 0 \\
Fontan & 1 & 0 & 0 \\
Bjork & 16 & 2 & 4 \\
\hline total & & & \\
\hline
\end{tabular}

時に行われ最長 23 年の生存が得られ，現在 2 期手術を 考慮中である。

症例 —(Ib.女）は，1才で Glenn 手術を行い 8 年後にチアノーゼ増強のため B-T 術を追加, 12 年後 (13才 $28.5 \mathrm{~kg}, 145 \mathrm{~cm}$ ) に Carpentier-Edwards \#18 弁付 conduit を用いて Fontan 手術に成功した（図 1). 術後 3 年経過した現在 $39 \mathrm{~kg} 154 \mathrm{~cm}$ と大きく成長し, 心カテで conduit 前後の圧差 $3 \mathrm{mmHg}$ ，PA 圧 $20 / 14$ (16) $\mathrm{mmHg}$ で，右房圧は平均 $18 \mathrm{mmHg} ， a$ 波 $23 \mathrm{~mm}$ $\mathrm{Hg}$ とアンギオ所見ともども右房の良好な収縮力を示し た.

症例 (Ib，女) は，2才時 B-T 術を行い，7才 時 $(21 \mathrm{~kg}, 122 \mathrm{~cm})$ チアノーゼ堌強, 運動能低下のため 機能的根治術に踏及切った，手術時巨大な右房と良く発 育した PA を認めたので自己心膜を用い Björk 手術を 行った（図 2). 術後 10 カ月, チアノーゼもとれ，25 $\mathrm{kg}, 126 \mathrm{~cm}$ と成長し著しい運動能の向上が認められた. 


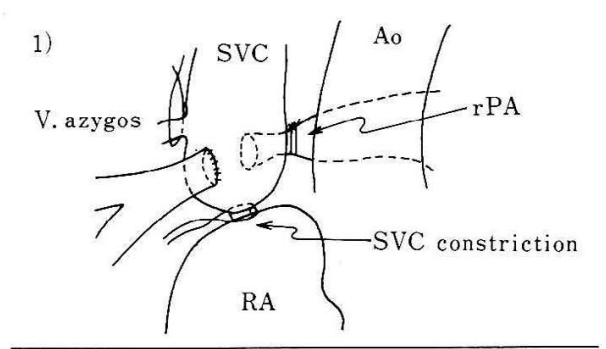

2)

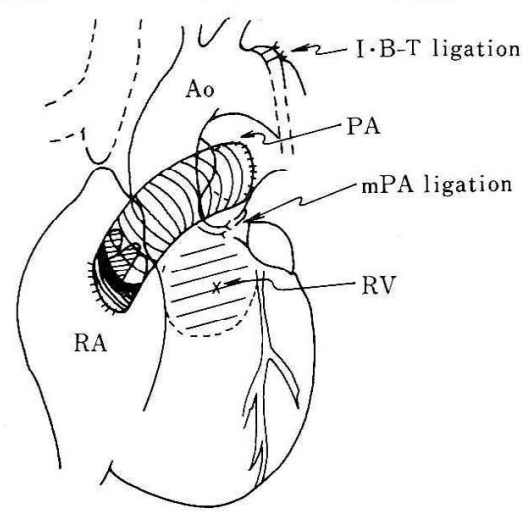

Tricuspid Atresia (Ib)

Iy $2 \mathrm{~m}, 8.3 \mathrm{~kg}, 73 \mathrm{~cm}$ Glenn procedure

$8 \mathrm{y} \quad 20 \mathrm{~kg}, 121 \mathrm{~cm}$ left Blalock-Taussig shunt

$13 \mathrm{y} \quad 28.5 \mathrm{~kg}, 145 \mathrm{~cm}$ Fontan procedure

図 1 Case Female

心カテで右房右室吻合部で $2 \mathrm{mmHg}$ の圧差を認めたが 右房圧平均 $14 \mathrm{mmHg}$, a 波 $24 \mathrm{mmHg}$ を示しアンギ オでも良好な右房収縮が認められた。

\section{考察と結語}

高肺血流群 (Ic, IIc) は生後 1 力月位の早期に肺血流 量のコントロールをはからない之予後は極めて不良であ る. 低肺血流量群では B-T 術, Glenn 術などで, 肺血 流量の増加をはからねばならない.

Glenn 手術は，10 才でこれを行った 2 症例が 12 年

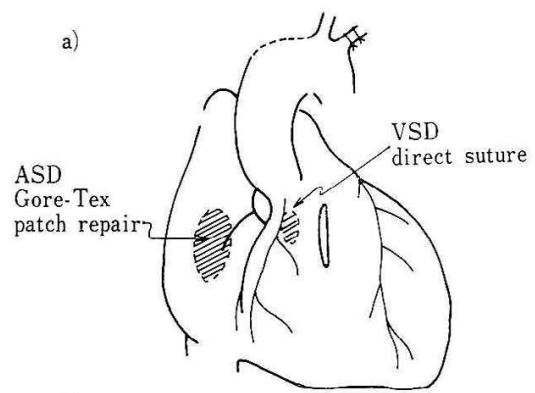

b)

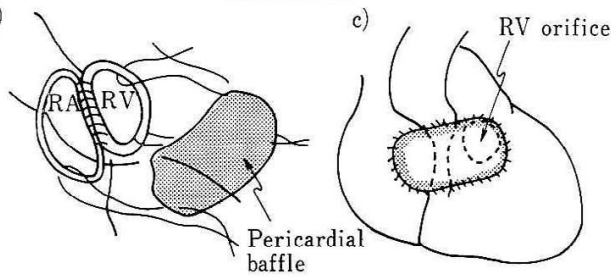

Tricuspid Atresia (Ib)

2y $2 \mathrm{~m} \quad 11 \mathrm{~kg}, \quad 85 \mathrm{~cm}$ left Blalock-Taussig shunt $7 \mathrm{y} 4 \mathrm{~m} \quad 21 \mathrm{~kg}, 122 \mathrm{~cm}$ Björk procedure

(RA-RV anastomosis)

図 2 Case Female

後, 16 年後に経過死亡していること, また 6 才で行っ た例が 23 年後元気に勤務していることから，本法施行 年令は 3 〜 才が最適と考えられた. 本法実施例は小览 期後半を目安に右心系血行再建を考慮すべきと考觉る. この際本法は右房に侵襲を加えていない点, 右心系ポン プとして右房を用いる根治術に有利となるなど優れた術 式と言える.

機能的根治術を行った 2 例は，右房流入部に人工升は 用いなかったが，術後 1 〜 年の心カテ・アンギオで右 房収縮運動は良好に保たれていることが示された。

Björk 手術は, 右心系血行再建に人工升やグラフトを 用いないので血栓形成, 感染, 耐性や成長などの点で将 来問題が少ないと考えられ, 用いらるべき術式の 1 つ 考えられた。 